\title{
INDONESIAN PALM OIL IN THE WORLD VEGETABLE OIL MARKET IN THE PERIOD OF 2004-2017: LEADER OR FOLLOWER?
}

\author{
Wanti Fitrianti $^{* * 1}$, Yusman Syaukat ${ }^{* *}$, Sri Hartoyo ${ }^{* * *}$, and Anna Fariyanti $\left.{ }^{* * * *}\right)$ \\ *) Faculty of Agriculture, Tanjungpura University \\ JL. Prof. Dr. H. Hadari Nawawi, Pontianak 78124 \\ ${ }^{* *}$ Department of Resource and Environmental Economics, Faculty of Economics and Management, \\ IPB University \\ J1. Agatis, IPB Darmaga Campus, Gd. Faculty of Economics and Management W3 L2 Bogor, 16680 \\ ${ }^{* * *}$ Departement of Economics, Faculty of Economics and Management, IPB University \\ Jl. Agatis, Campus of IPB Darmaga Bogor 16680 \\ ${ }^{* * * *)}$ Department of Agribusiness, Faculty of Economics and Management, IPB University \\ Jl. Agatis, Campus of IPB Darmaga Bogor 16680
}

\begin{abstract}
This research specifically analyzed the market integration and transmission of Indonesian palm oil prices in the world vegetable oil market. The analysis using the Threshold Vector Error Correction Model approach was based on time series on the palm oil, soybean oil, rapeseed oil and sunflower oil prices for the period of January 2004 to June 2017. The findings proved the existence of market integration and transmission of asymmetric prices marked by price increases transmitted more quickly among the vegetable oil markets in the long run. The main findings of this research indicated that there was an intense competition between the vegetable oil market and the price of Indonesian palm oil which still followed the rising price of Malaysian palm oil, soybean oil, and rapeseed oil prices, but it was still the leader in the movement of sunflower oil prices. However, the long-term period of soybean oil prices followed a decline in the price of Indonesian palm oil. The results of this research imply that Indonesian palm oil has the opportunity to strengthen its position in the world vegetable oil market by developing futures exchanges that are supported by the adequate physical trading market infrastructure so that it can become the center of formation and reference for world palm oil prices.
\end{abstract}

Keywords: market integration, palm oil, vegetable oil, threshold

\begin{abstract}
Abstrak: Tujuan studi ini secara khusus menganalisis integrasi pasar dan transmisi harga minyak sawit Indonesia di pasar minyak nabati dunia. Analisis yang digunakan dengan pendekatan Threshold Vector Error Corection Model berdasarkan data time series harga minyak sawit, minyak kedelai, minyak rapeseed dan minyak bunga matahari untuk periode Januari 2004 sampai Juni 2017. Hasil temuan membuktikan adanya integrasi pasar dan transmisi harga asimetris ditandai dengan kenaikan harga akan lebih cepat ditransmisikan antara pasar minyak nabati dalam jangka panjang. Temuan utama penelitian ini menunjukkan adanya persaingan yang ketat antara pasar minyak nabati serta harga minyak sawit Indonesia masih menjadi follower terhadap pergerakan kenaikan harga minyak sawit Malaysia, minyak kedelai serta harga minyak rapeseed dan sebaliknya menjadi leader terhadap pergerakan harga minyak bunga matahari. Namun, periode jangka panjang harga minyak kedelai menjadi follower terhadap penurunan harga minyak sawit Indonesia. Hasil penelitian ini mengimplikasikan minyak sawit Indonesia memiliki peluang untuk memperkuat posisi di pasar minyak nabati dunia dengan mengembangkan bursa berjangka yang didukung dengan infrastruktur pasar perdagangan fisik yang memadai sehingga dapat menjadi tempat pembentukan dan rujukan utama harga minyak sawit dunia.
\end{abstract}

Kata kunci: integrasi pasar, minyak sawit, minyak nabati, threshold

\footnotetext{
${ }^{1}$ Corresponding author:

Email: fitriewantie@gmail.com
} 


\section{INTRODUCTION}

Palm oil, soybean oil, rapeseed oil, and sunflower oil are the four main types of oil produced and traded in the world market of vegetable oils. The share of the four main vegetable oil production to the total world vegetable oil production increased from $61 \%$ in 1991 to $82 \%$ in 2016 with the dominance of palm oil by $35 \%$, soybean oil by $25 \%$, and rapeseed oil and sunflower by 22\% (Oil World, 2017). Meanwhile, the total share of the four types of vegetable oil in the world vegetable oil trade in 2015 was $93.53 \%$. In fact, Indonesia and Malaysia have become the largest producers and exporters controlling $90 \%$ of the trade in palm oil in the world vegetable oil market (USDA, 2016).

The similarity of use among vegetable oils shows a substitution or complementary relationship that will have implications for market integration so that the prices will influence one another (Suryana, 1986; Purwanto, 2002; Buyung et al. 2017) and may not deviate from each other, at least in the long run (Priyati and Tyears 2016). Various findings from empirical research also prove that the linkage among vegetable oil prices is one indicator of market integration and price transmission process among vegetable oils (Costa and Castana, 2015). In fact, the research conducted by Arianto et al. (2010) highlighted that the price of palm oil is the price leader in the vegetable oil market complex.

Contradictory to the results of the research carried out by Owen et al. (1997), they showed that the price of palm oil had a low interaction with other oil prices, but greater interaction was found among soybean oil and sunflower oil. This result was consistent with the findings of In and Inder (1997) stating that cointegration only occurred among sunflower, soybean and rapeseed oils. Soybean oil is a leader in pricing among various vegetable oils because of its price flexibility so that it is used as a reference for other vegetable oils and makes palm oil a price taker (Amiruddin et al. 2005; Aji, 2010; Abdullah, 2013). Thus, the influence of the soybean oil price on the world market today is still greater than the palm oil price in the Rotterdam market (Aji, 2010; Abdullah, 2013). The consequence of the substitution role among vegetable oils has led to the formation mechanism of vegetable oil prices to be interrelated, especially between palm oil and soybean oil (Abdullah, 2013).
The basic theory of market integration analysis is Law One Price (LOP) stating that free trade is arbitrage if the price of homogeneous goods in spatially separate markets must be the same after being adjusted for transportation costs and exchange rates (Ardeni, 1989). If this applies, the market is considered to be perfectly integrated, and changes in prices in one market must be transmitted perfectly at prices in other markets. Many studies have tested LOP to assess various products and markets. There is little evidence to support the LOP theory, and there is a growing consensus that many factors influence the transmission signal of prices from one market to another under perfectly competitive market conditions. Some factors often cited are the presence of agents with market power, border distortion, domestic policies and homogeneity, and product differentiation.

The results of several studies demonstrated differences that strenghten the assumptions of asymmetric transmission in the long-term adjustment among vegetable oil prices. Asymmetric transmission is due to trade policies applied among vegetable oil producers and differences in geographical location. Kouyate and Von Cramon Taubadel (2016) also showed that distance and international borders reduce cointegration and slow down price adjustments. The adjustment time lag also indicates an asymmetrical price transmission (Nakajima, 2012).

This research focused on price transmission that refers to the condition of non-imperfect market structures as the explanation of LOP failure (Mayer \& Von Cramon Taubadel, 2004; Abdulai, 2000). LOP failure is one factor that causes asymmetry in price transmission and a slow adjustment of international market prices to the domestic market prices (Vavra and Goodwin, 2005). The asymmetry of price transmission can be a manifestation of market failure that induces pass through imperfections between export prices in international markets and prices in domestic markets (Vavra and Goodwin, 2005).

Faced with anomalies that cause of asymmetric price transmission, the cointegration technique using the Engle Granger and Johansen models was no longer appropriate. Balke and Fomby (1997) stated that the adjustments to long-term equilibrium can vary in various economic conditions. On contrary, VECM highlighted that deviations were corrected in the same way both in an increase and decrease. Therefore, if the relationship 
pattern between deviations and short-term dynamics is nonlinear, the VECM model is not appropriate for describing short-term relationships among variables. The cointegration threshold concept, as introduced by Balke and Fomby (1997), can reveal that the nonlinear adjustment pattern among variables with the basic idea of the cointegration threshold model is to form more than one time series model regime divided based on error correction term (ECT). Moreover, cointegration threshold model was developed by Hansen Seo (2002), known as the Threshold Vector Error Correction Model (TVECM), which allows non-linear adjustments to long-run equilibrium based on conditions limited by a threshold, creating two or more different conditions. In other words, the threshold effect on the TVECM model depends on the amount of imbalance in the system in the long run so that this method is able to detect more complex co-movements from the data series.

The study of vegetable oil prices using the TVECM model is still limited. Peri and Baldi (2010) analyzed the long-term relationship between the prices of vegetable oil and diesel oil in the European Union for the period of 2005-2007 based on the procedures of Hansen and Seo (2002) and found a cointegration relationship between the prices of rapeseed oil and diesel oil in the case of cointegration threshold. However, there was no cointegration relationship between diesel oil and sunflower oil or soybean oil.

Another study conducted by Goetz and Von CramonTaubadel (2008) applied the threshold cointegration model on apple prices at the wholesale level in Hamburg and Munich market by identifying four price transmission regimes marked by the results that show the different balance relationships and shortterm adjustment processes. Rapsomanikis and Hallam (2006) used TVECM to test linearity on adjusting the price of sugar and ethanol to crude oil prices in Brazil and found a nonlinear threshold.

The combination of different cointegration analysis confirms the argument that non-linear and cointegration threshold techniques represent more real conditions in the market where information is asymmetrical, and transaction costs cause non-linear results. Research that comprehensively estimates the relationship of market integration and price transmission among major vegetable oils using the cointegration threshold approach is still lacking. This research was conducted to fill in the gap by testing the hypothesis of the possibility of asymmetric and threshold relationships in adjusting prices among vegetable oils. Thus, the purpose of this research was specifically analyzing the transmission of the Indonesian palm oil asymmetric price on the world vegetable oil market using TVECM developed by Hansen and Seo (2002).

\section{METHODS}

This research used secondary data in the form of monthly time series from January 2004 to June 2017. The data consisted of major vegetable oils prices on world markets including Indonesian palm oil (CPOI), Malaysian Palm Oil (CPOM), Chicago soybean oil (SOYA), Rotterdam rapeseed oil (RAPE) and USA sunflower oil (SUN). The data sources were taken from Reuters and the International Monetary Fund (IMF). All prices were in the same exchange rate (USD/Ton) stated in nominal form and natural logarithms.

The analytical method used in this research was the Threshold Vector Error Correction Model (TVECM). Data processing in the analysis utilized Eviews 09 and R 3.3.3 software. Threshold cointegration proposed by Balke and Fomby (1997) was a feasible technique for combining non-linearity and cointegration. Linear model framework assumed that the deviation towards long-run equilibrium was corrected linearly. However, non-linearity in inter-market relations might occur due to marketing costs, price rigidity, and market strength or risk. TVECM relaxed the restrictions on linear models. Price adjustments did not occur instantaneously, yet it only occurred if the deviation exceeded the critical threshold allowing the band to arbitrate or not.

TVECM will improve the cointegration analysis capabilities in the case of integration and transmission of asymmetry prices in the context of the world vegetable oil market which can represent real world economic phenomena by loosening the assumption that the speed of the cointegrated series move toward a constant, long-term balance relationship over time. In particular, this model allowed for nonlinear adjustments to longrun equilibrium. Before entering the TVECM model, pre-estimation tests were carried out such as data stationarity test and cointegration test to determine comovement among the markets and followed by Hansen Seo's supLM test (2002) as shown in Figure 1. 


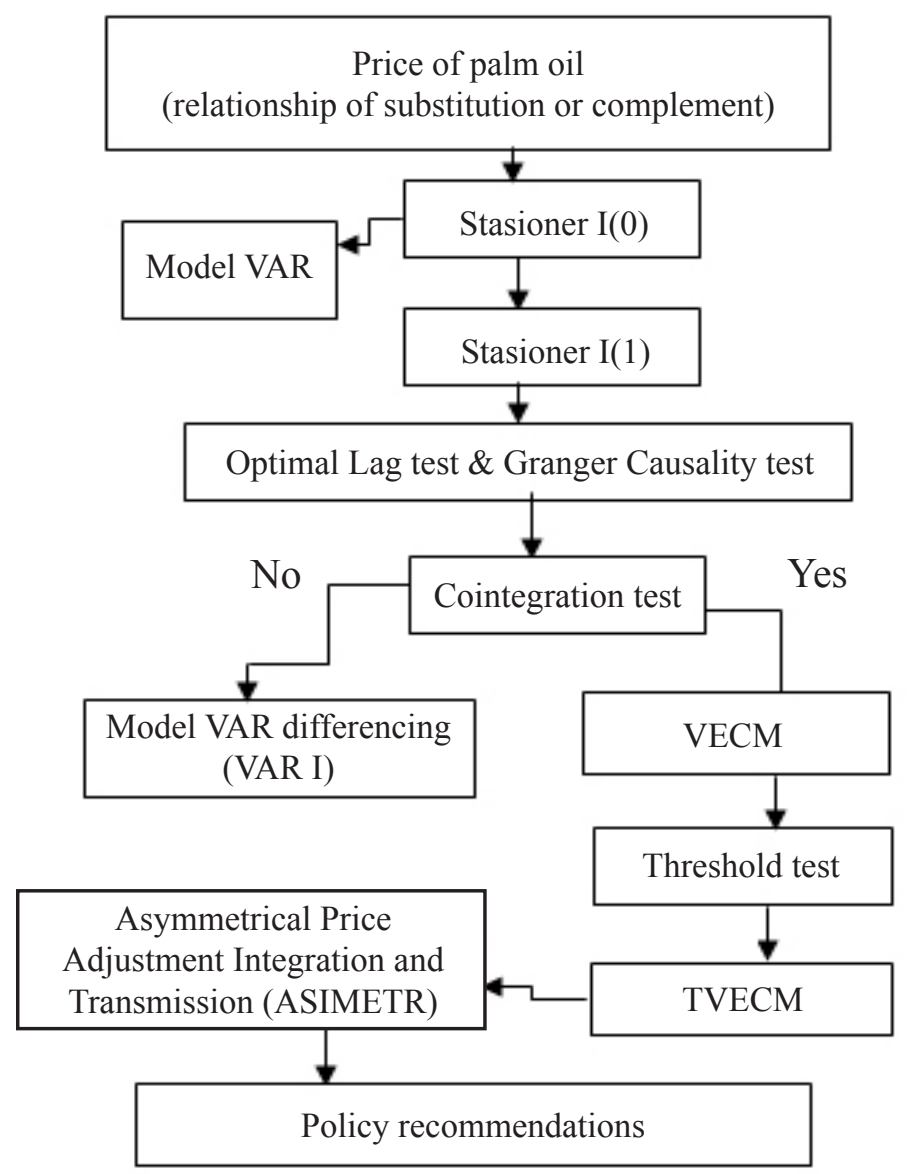

Figure 1. Research framework

Tests on the presence of threshold by using Sup Langrange Multiplier Test (LM Test) with the hypothesis as follow:

H0: $\mathrm{A} 1=\mathrm{A} 2$ or model is VECM linear

H1: $\mathrm{A} 1 \neq \mathrm{A} 2$ or model is VECM Threshold

VECM results were used as the basis for the threshold calculation using the algorithm proposed by HansenSeo to find the minimum Log Likelihood value from the model that had been formed. The p-value of this test was obtained by calculating the percentage of the simulation sample boost that the LM * sup value exceeded the supLM value. SupLM statistics had an asymptotic non-standard distribution and suggested two bootstarp techniques for estimating $\mathrm{p}$ values from the test: the first one was fixed bootstrap regression and the other was bootstrap residual with 1000 replication simulations (Stiegler, 2010). The SupLM test formula is written as follows:

$\operatorname{SupLM}=\operatorname{SupLM}(\beta, \gamma)$

$$
\gamma_{\mathrm{L}} \leq \gamma \leq \gamma_{\mathrm{U}}
$$

in which $\gamma$ is threshold value, equals to $\lambda: \gamma_{L}$ adalah $\Pi_{0}$ percentile of wt $1(\beta): \gamma u$ is $1-\Pi_{0} 1-\Pi_{0}$ percentile. In which:

$$
\begin{aligned}
& \mathrm{LM}(\beta, \gamma)=\operatorname{vec}\left(\mathrm{A}_{1}(\beta, \gamma)-\mathrm{A}_{2}(\beta, \gamma)\right)^{\prime}\left(\left(\mathrm{V}_{1}(\beta, \gamma)+\left(\mathrm{V}_{2}(\beta, \gamma)\right)^{-1}\right.\right. \\
& { }^{*} \operatorname{vec}\left(\mathrm{A}_{1}(\beta, \gamma)-\mathrm{A}_{2}(\beta, \gamma)\right)
\end{aligned}
$$

The two regimes of Threshold Vector Error Correction Model (TVECM) testing carried out in this research adopted the approach model proposed by Hansen and Seo (2002). One cointegration vector and threshold parameter were used based on error correction term. The models used can be stated as follows:

$\Delta P_{t}= \begin{cases}\alpha^{1} \omega_{t-1}(\beta)+\sum_{t=1}^{k-1} r_{t}^{1} \Delta P_{t-1}+\varepsilon_{t}^{1} & \text { if } \omega_{t-1}(\beta) \leq \gamma_{1} \\ \alpha^{2} \omega_{t-1}(\beta)+\sum_{t=1}^{k-1} r_{t}^{2} \Delta P_{t-1}+\varepsilon_{t}^{2} & \text { if } \omega_{t-1}(\beta)>\gamma_{2}\end{cases}$

Furthermore, equation 1 is described in equation 2 (Regime 1) and Equation 3 (Regime 2)

$$
\left.\begin{array}{rl}
\Delta P X_{t}=\theta_{11} & +\alpha^{1} \omega_{t-1}(\beta)+\lambda^{1}{ }_{111} \Delta P X_{t-1}+\lambda^{1}{ }_{121} \Delta P Y_{t-1} \\
& +\lambda^{2}{ }_{112} \Delta P X_{t-n}+\lambda^{1}{ }_{122} \Delta P Y_{t-n}+\varepsilon_{t}^{1} \\
\Delta P Y_{t}=\theta_{12} & +\alpha^{1} \omega_{t-1}(\beta)+\lambda^{1}{ }_{211} \Delta P Y_{t-1}+\lambda^{1}{ }_{221} \Delta P X_{t-1} \\
& +\lambda^{2}{ }_{212} \Delta P Y_{t-n}+\lambda^{1}{ }_{222} \Delta P X_{t-n}+\varepsilon_{t}^{2}
\end{array}\right\} \text { if } \omega_{t-1}(\beta) \leq \gamma_{1}
$$




$$
\left.\begin{array}{rl}
\Delta P X_{t}=\theta_{21}+\alpha^{2} \omega_{t-1}(\beta)+\lambda^{2}{ }_{111} \Delta P X_{t-1}+\lambda^{2}{ }_{121} \Delta P Y_{t-1} \\
+ & \lambda^{2}{ }_{112} \Delta P X_{t-n}+\lambda^{2}{ }_{122} \Delta P Y_{t-n}+\varepsilon_{t}^{2} \\
\Delta P Y_{t}=\theta_{22}+\alpha^{2} \omega_{t-1}(\beta)+\lambda^{2}{ }_{211} \Delta P Y_{t-1}+\lambda^{2}{ }_{221} \Delta P X_{t-1} \\
+\lambda^{2}{ }_{212} \Delta P Y_{t-n}+\lambda^{2}{ }_{222} \Delta P X_{t-n}+\varepsilon_{t}^{2}
\end{array}\right\} \text { if } \omega_{t-1}(\beta)>\gamma_{2}
$$

in which: $\triangle \mathrm{PX}_{\mathrm{t}}$ (Indonesian palm oil price (CPOI) (USD/Ton)); $\Delta \mathrm{PY}_{\mathrm{t}}$ (world's vegetable oil price covering Malaysian palm oil, (CPOM), Chicago soybean oil (SOYA), Rotterdam rapeseed oil (RAPE), USA sunflower seed (SUN) (USD/Ton)); $\omega_{t-1}(\beta)$ (error correction term representing threshold variable (ECT)); $\gamma$ (threshold parameter separating two regimes).

\section{RESULTS}

The first step to analyze the integrated vegetable oil model with the Threshold Vector Error Correction approach was to test the data stationarity of palm oil, soybean, rapeseed and sunflower prices. Stationarity testing was carried out to examine the consistency of time series data movements to prevent spurious regression. Stationarity testing used the Augmented Dickey Fuller Test (ADF) with real levels of 1\%, 5\% and $10 \%$. ADF test was calculated for each price with an intercept and without a deterministic trend. This test was conducted at level and first difference. If the data were not stationary at the level, the test would continue in the condition of first order (differencing). Furthermore, if the t-ADF value was smaller than Mackinon's critical value, the data used were stationary. The results of the ADF stationarity test in Table 1 showed data on prices of vegetable oils (palm oil, soybean oil, rapeseed oil and sunflower oil) which were analyzed by using intercept criteria without trends were stationary at first difference. This was indicated by the ADF value smaller than the critical value of MacKinnon.

Before conducting the cointegration test, the optimal lag test was determined based on the value of the Akaike Information Criterion, and the optimal lag 2 length was obtained; then, the Granger Causality test referring to the causal relationship between the price of vegetable oil was carried out. Cointegration tests using the Johansen method were conducted by using bivariate data for each price of Indonesian palm oil and Malaysian palm oil, soybean oil, rapeseed oil, and sunflower oil. Johansen's test in this research was carried out by comparing the trace statistic values with the critical value and maximum eigenvalue with critical value at 5\% level. Based on Table 2, all prices of Indonesian palm oil variable on other vegetable oils have a trace statistical value greater than the $5 \%$ of critical value meaning that there is 1 equation that shows a cointegration relationship among the variables in the model. This means that among the prices of vegetable

\begin{tabular}{|c|c|c|c|c|c|c|}
\hline \multirow{3}{*}{ Variabel } & \multirow{3}{*}{ Orde } & \multicolumn{4}{|c|}{ Intercept No Trend } & \multirow{3}{*}{ Summary } \\
\hline & & \multirow{2}{*}{ ADF Test } & \multicolumn{3}{|c|}{ MacKinnon Critical Value } & \\
\hline & & & $1 \%$ & $5 \%$ & $10 \%$ & \\
\hline \multirow[t]{2}{*}{ CPOI } & $\mathrm{I}(0)$ & -2.230 & -3.471 & -2.879 & -2.576 & No Stationarity \\
\hline & $\mathrm{I}(1)$ & -8.841 & -3.471 & -2.879 & -2.576 & Stationarity \\
\hline \multirow[t]{2}{*}{ СРОМ } & $\mathrm{I}(0)$ & -2.103 & -3.471 & -2.879 & -2.576 & No Stationarity \\
\hline & $\mathrm{I}(1)$ & -8.382 & -3.471 & -2.879 & -2.576 & Stationarity \\
\hline \multirow[t]{2}{*}{ SOYA } & $\mathrm{I}(0)$ & -1.743 & -3.471 & -2.879 & -2.576 & No Stationarity \\
\hline & $\mathrm{I}(1)$ & -8.934 & -3.471 & -2.879 & -2.576 & Stationarity \\
\hline \multirow[t]{2}{*}{ RAPE } & $\mathrm{I}(0)$ & -2.107 & -3.471 & -2.879 & -2.576 & No Stationarity \\
\hline & $\mathrm{I}(1)$ & -9.933 & -3.471 & -2.879 & -2.576 & Stationarity \\
\hline \multirow[t]{2}{*}{ SUN } & $\mathrm{I}(0)$ & -3.063 & -3.471 & -2.879 & -2.576 & No Stationarity \\
\hline & $\mathrm{I}(1)$ & -8.116 & -3.471 & -2.879 & -2.576 & Stationarity \\
\hline
\end{tabular}
oils, there is a long-term balance relationship.

Table 1. Data stationarity test of vegetable oil prices 
Table 2. Co-integration test of vegetable oil price

\begin{tabular}{lcccc}
\hline Total Cointegration & Trace Statistic & Critical Value $5 \%$ & Max-Eigen Statistic & Critical Value $5 \%$ \\
\hline CPOI-CPOM & & & & \\
$\mathrm{r}=0$ & 58.72796 & 12.32090 & 58.72639 & 11.22480 \\
$\mathrm{r} \leq 1$ & 0.001568 & 4.129906 & 0.001568 & 4.129906 \\
CPOI-SOYA & & & & \\
$\mathrm{r}=0$ & 33.17528 & 25.87211 & 27.54888 & 19.38704 \\
$\mathrm{r} \leq 1$ & 5.626394 & 12.51798 & 5.626394 & 12.51798 \\
$\mathrm{CPOI}-\mathrm{RAPE}$ & & & & \\
$\mathrm{r}=0$ & 25.00679 & 18.39771 & 20.38132 & 17.14769 \\
$\mathrm{r} \leq 1$ & 4.625476 & 3.841466 & 4.625476 & 3.841466 \\
$\mathrm{CPOI}-\mathrm{SUN}$ & & & & \\
$\mathrm{r}=0$ & 26.60213 & 20.26184 & 19.55180 & 15.89210 \\
$\mathrm{r} \leq 1$ & 7.050327 & 9.164546 & 7.050327 & 9.164546 \\
\hline
\end{tabular}

Furthermore, the results of the cointegration threshold test using the SupLM test rejected the null hypothesis for thelinear VECM model showing potential for a threshold effect so that the TVEC model was appropriately used in estimating the vegetable oil price model. Based on TVECM estimation results, the relationship between Indonesian and Malaysian palm oil prices shown in Table 3 shows that the ECT coefficient value was significant only in Indonesian palm oil price equation model at regimes 1 and 2. These results indicated that the behavior of Indonesian palm oil prices would respond significantly to imbalances when the amount of deviation (ECT) was below and above certain threshold value. The threshold value was indicated by a threshold value of 0.004 . The magnitude of the ECT coefficient at regime 1 was -0.41 . This meant that when there was a deviation of less than $0.4 \%$, the price of Indonesian palm oil would be corrected by $41 \%$ from the previous period of imbalance with a length of adjustment of 1.3 months to return to the long-term balance.

Based on the magnitude of the ECT coefficient at regime 2 of -0.63 , when there was an imbalance (deviation) of more than $0.4 \%$, the price of Indonesian palm oil would be corrected by $63 \%$ from the previous period imbalance with a length of adjustment of 0.6 months to return to the long-term balance. The ECT coefficient value showed that the response of the price of Indonesian palm oil was greater than the price of Malaysian palm oil in the long-term balance when there was an imbalance in the short term. Besides, the significant ECT value was only on the price of Indonesian palm oil, the long-term causality only occurred in the price of Malaysian palm oil to the price of Indonesian palm oil. In other words, the price of Malaysian palm oil affected the price of Indonesian palm oil in the long term period.

The TVECM estimation results implied the price of Malaysian palm oil as the leader and the price of Indonesian palm oil as the follower, thus affecting the formation of Indonesian palm oil prices. In the long run, a $1 \%$ increase in the price of Malaysian palm oil will cause a price increase of $1.03 \%$ for the price of Indonesian palm oil. To date, the price of Indonesian domestic palm oil still refers to and is influenced by the price of palm oil in world markets, especially the physical market in Rotterdam and the futures market Malaysian Derivative Exchange (MDEX) (Chalil, 2016). Export competition between the two countries can also contribute to market integration. It is in line with the Chalil's study (2016) revealing the presence of price integration and transmission between the two markets. This proves that the palm oil market is not fragmented even though it is geographically separated. Other important results in the estimation result indicate that the price of Indonesian palm oil will respond quickly to the increase in the price of Malaysian palm oil to reach its balance. This result indicates that the price of Malaysian palm oil will receive a positive margin ahead of the price of Indonesian palm oil. 
Table 3. Results of TVECM Estimated Prices of Indonesian Palm Oil (CPOI), Malaysia (CPOM) and Soybean Oil (SOYA)

\begin{tabular}{|c|c|c|c|c|c|c|c|c|c|c|c|}
\hline \multirow{3}{*}{$\overline{E C T_{t}}$} & \multicolumn{2}{|c|}{ TVECM REGIME $1(44 \%)$} & & \multicolumn{2}{|c|}{ TVECM REGIME $2(56 \%)$} & \multicolumn{4}{|c|}{ TVECM REGIME 1 (95\%) } & \multicolumn{2}{|c|}{ TVECM REGIME $2(5 \%)$} \\
\hline & \multirow{2}{*}{$\frac{\triangle C P O I_{t}}{(-0.4094)^{*}}$} & \multirow{2}{*}{$\triangle C P O M_{\mathrm{t}}$} & \multirow{2}{*}{$E C T_{t}$} & \multirow{2}{*}{$\frac{\triangle C P O I_{\mathrm{t}}}{(-0.6363)^{*}}$} & \multirow{2}{*}{$\frac{\triangle C P O M_{\mathrm{t}}}{-0.501}$} & \multirow[b]{2}{*}{$E C T_{\mathrm{t}}$} & \multirow{2}{*}{$\frac{\triangle S O Y A_{\mathrm{t}}}{(-0.0762)^{*}}$} & \multicolumn{2}{|c|}{$\triangle C P O I_{\mathrm{t}}$} & \multirow{2}{*}{$\frac{\Delta S O Y A_{\mathrm{t}}}{0.1811}$} & \multirow{2}{*}{$\frac{\triangle C P O I_{\mathrm{t}}}{1.2613^{* *}}$} \\
\hline & & & & & & & & 0.0054 & $E C T_{\mathrm{t}}$ & & \\
\hline & {$[0.0482]$} & {$[-0.5641]$} & & {$[0.0887]$} & {$[0.1715]$} & & {$[0.0626]$} & {$[0.9177]$} & & [0.6291] & {$[0.0091]$} \\
\hline \multirow[t]{2}{*}{ Intercept } & -0.0018 & -0.0014 & Intercept & 0.0155 & 0.014 & Intercept & 0.0004 & 0.0017 & Intercept & $(-0.0626)$ & $(-0.3306)^{*}$ \\
\hline & {$[-0.8362]$} & {$[0.8716]$} & & {$[0.2437]$} & [0.2839] & & {$[-0.9315]$} & {$[-0.7685]$} & & {$[-0.6259]$} & {$[0.0450]$} \\
\hline \multirow[t]{2}{*}{$\triangle C P O I_{\mathrm{t}-1}$} & $(-0.5308)$ & $(0.5885) *$ & $\triangle C P O I_{\mathrm{t}-1}$ & 0.539 & 0.6492 & $\triangle S O Y A_{t-1}$ & $0.2424 *$ & 0.2333 & $\triangle S O Y A_{t-1}$ & $(-0.6947)$ & $(-1.2631)^{*}$ \\
\hline & {$[0.0392]^{*}$} & {$[0.0201]$} & & [0.2459] & [0.1551] & & {$[0.0380]$} & {$[-0.1165]$} & & {$[-0.1425]$} & {$[0.0374]$} \\
\hline \multirow[t]{2}{*}{$\triangle C P O M_{\mathrm{t}-1}$} & $0.8207 * *$ & $0.8443 * *$ & $\triangle C P O M_{\mathrm{t}-1}$ & 0.0577 & $(-0.071)$ & $\triangle C P O I_{t-1}$ & 0.0024 & 0.1736 & $\triangle C P O I_{\mathrm{t}-1}$ & $(0.9101)^{* *}$ & $1.6772 * * *$ \\
\hline & {$[0.0025]$} & {$[0.0015]$} & & [0.9038] & {$[0.8795]$} & & {$[-0.979]$} & {$[-0.1398]$} & & {$[0.0030]$} & {$[2.5 e-05]$} \\
\hline \multirow[t]{2}{*}{$\triangle C P O I_{\mathrm{t}-2}$} & 0.2573 & 0.1424 & $\triangle C P O I_{t-2}$ & 0.7222 & 0.5712 & $\triangle S O Y A_{t-2}$ & 0.0619 & -0.0354 & $\triangle S O Y A_{t-2}$ & $(-0.2676)$ & $(-1.0747)^{*}$ \\
\hline & {$[-0.3224]$} & {$[-0.5766]$} & & {$[0.122]$} & {$[0.2122]$} & & {$[-0.6037]$} & {$[-0.816]$} & & {$[-0.5328]$} & {$[0.0510]$} \\
\hline \multirow[t]{2}{*}{$\triangle C P O_{t-2}$} & $(-0.4061)$ & $(-0.269)$ & $\triangle C P O M_{\mathrm{t}-2}$ & $(-0.7453)$ & $(-0.6595)$ & $\triangle C P O I_{\mathrm{t}-2}$ & -0.0458 & -0.0569 & $\triangle C P O I_{t-2}$ & 0.3272 & $0.8394 * *$ \\
\hline & {$[-0.1588]$} & {$[-0.3408]$} & & {$[0.1209]$} & {$[0.1619]$} & & [0.6439] & {$[-0.6527]$} & & {$[-0.1659]$} & {$[0.0058]$} \\
\hline \multicolumn{6}{|c|}{ AIC: -2088.47 ; SSR: 1.3018 ; Threshold: 0.0044151} & \multicolumn{6}{|c|}{ AIC: -1884.552 ; SSR: 1.11677 ; Threshold: 0.2285219} \\
\hline \multicolumn{6}{|c|}{ Cointegration Vector : $1,-1.000381)$} & \multicolumn{6}{|c|}{ Cointegrating vector: $(1,-1.028005)$} \\
\hline \multicolumn{6}{|c|}{ SupLM test: 23.79 : fixed, residual boostrap $(0.16 ; 0.03)$} & \multicolumn{6}{|c|}{ SupLM test: 21.15033 : fixed, residual boostrap $(0.096 ; 0.081)$} \\
\hline
\end{tabular}

Description: $* * *, * * *$ significant at $1 \%, 5 \%$ and $10 \%$; The first line shows the estimated coefficient; The second line shows the standard error.

TVECM estimation results in Regime 1 for the relationship between the price of Indonesian palm oil and soybean oil in Table 3 showed that the ECT coefficient value was significant only in the model of the soybean oil price equation. This indicated that the behavior of soybean oil prices would respond significantly to imbalances when the deviation (ECT) was below the threshold value of 0.22 . This means that when there was an imbalance (deviation) of less than $22 \%$, soybean oil prices would be corrected by $7 \%$ from the magnitude of the imbalance in the previous period with a length of adjustment of 8.7 months to return to the long-term balance. This result implied that the price of soybean oil would respond to the decline in prices compared to the increase in the price of Indonesian palm oil.

Furthermore, in regime 2 (top regime), the ECT value was significant only in the Indonesian palm oil price equation; i.e. 1.261 in Table 3. This means that when there was a deviation of more than $22 \%$, Indonesian palm oil prices would be corrected by $126 \%$ from the previous period of imbalance with a 0.5 month adjustment period to return to the long-term balance. The ECT coefficient value was positive and greater for the price of Indonesian palm oil compared to soybean oil prices at regime 2 . This indicated that when the price of Indonesian palm oil fell below the balance level, especially when the price fell down very low, it would more quickly adjust up to its balance condition and imply the effect of soybean oil prices on the formation of Indonesian palm oil prices. These results indicated that the price of Indonesian palm oil responded to the rise in soybean oil prices. In the long run, a $1 \%$ price increase in soybean oil prices will cause a price increase by $1.02 \%$ for the price of Indonesian palm oil. This is in line with the study of Chuangchid (2012) demonstrating a strong dependence on the prices of palm oil and soybean oil. The competition between the prices of both vegetable oils can contribute to market integration. In addition to market competition, differences in the quality of oil can contribute to the threshold adjustment in the prices of Indonesian palm oil and soybean oil. The price of soybean oil enjoys premium quality over the price of Indonesian palm oil, making it possible for Indonesia to respond to any increase that has occurred in soybean oil prices. In particular, positive price transmission asymmetry (when price declines continue to be faster than price increases) means showing competition between vegetable oil prices, while negative price transmission asymmetry (when price increases continue faster than price declines) indicates the possibility of a market power (Meyer and Von Cramon-Taubadel, 2004).

Based on Table 4, the results of TVECM estimation in Regime 1 (lower regime) found no adjustment between palm oil and rapeseed. Furthermore, regime 2 (top regime) showed that ECT value was significant only at Indonesian palm oil price of 0.422 with a threshold value of (0.22). This means that when there is an imbalance (deviation) of more than $22 \%$ then to return 
to the long-term balance of the price of Indonesian palm oil will be corrected by $42 \%$ from the previous period of imbalance with a length of adjustment of 1.2 months. The ECT coefficient value is positive and greater for the price of Indonesian palm oil than the price of rapeseed oil at regime 2 . The estimation results show that the price of Indonesian palm oil responds quickly to any price increase that occurs in rapeseed oil prices to the level of balance. In the long run, a $1 \%$ increase in the price of rapeseed oil will cause a price increase of $1.05 \%$ in the price of Indonesian palm oil. These results are consistent in many analyses of empirical studies which show that transmission of prices for agricultural products will respond more quickly to price increases than price decreases (Fiamohe et al. 2013).

The similarity of the model of sunflower oil prices in the long term is influenced by the movement of Indonesian palm oil prices, and there is no visible long-term balance adjustment in the Indonesian palm oil price equation model which is characterized by an insignificant ECT value (Table 4). In the long term, the price of significant sunflower oil will adjust the deviation due to shock $\leq 28 \%$ of the decline in the price of palm oil, and it takes at least 10.5 months to return to balance. and it will be faster to make adjustments only for 0.3 months when there is a shock of an increase in the price of Indonesian palm oil $>28 \%$ to return to balance. In the long run, if there is an increase in the price of $1 \%$ palm oil, the price of sunflower oil will respond to an increase of $0.93 \%$. This is trengthened by research by Fernandez-Amador et al. (2010) using TVECM to assess the existence of price asymmetry in the dairy product market in Austria, which showed transmission of asymmetric prices triggered by large deviations from balance and price trends

\section{Managerial Implications}

Adjustment of asymmetry prices was examined in the world vegetable oil market to provide more insights into the nature of competition among vegetable oils. This research was conducted to analyze more in the phenomenon of the market integration relationship of vegetable oils in the context of nonlinear adjustments using the threshold concept approach that can combine asymmetric linear relationship in cointegration relationship and use the regime as a price adjustment process as a factor in transitioning market integration. Figure 2 shows the price adjustment movement with the cointegration thresholds, asymmetric transmission, and strong support for market integration and transmission among the prices of Indonesian palm oil, Malaysian palm oil, prices of soybean oil, rapeseed oil and sunflower oil. The results of this research are consistent with some large price transmission literature that rarely finds supporting evidence for LOP. Peltzman survey (2002) found that asymmetric price transmission was mostly more prominent than symmetrical price transmission for agricultural products.

Table 4. Results of TVECM Estimates of Indonesian Palm Oil (CPOI) with Rapeseed Oil (RAPE) and Sunflower oil (SUN)

\begin{tabular}{|c|c|c|c|c|c|c|c|c|c|c|c|}
\hline \multicolumn{3}{|c|}{ TVECM REGIME $1(78.6 \%)$} & \multicolumn{3}{|c|}{ TVECM REGIME $2(21.4 \%)$} & \multicolumn{4}{|c|}{ TVECM REGIME $1(91.8 \%)$} & \multicolumn{2}{|c|}{ TVECM REGIME $2(8.2 \%)$} \\
\hline & $\triangle R A P E_{\mathrm{t}}$ & $\triangle C P O I_{\mathrm{t}}$ & & $\triangle R A P E_{\mathrm{t}}$ & $\triangle C P O I_{t}$ & & $\triangle C P O I_{t}$ & $\Delta S U N_{\mathrm{t}}$ & & $\triangle C P O I_{t}$ & $\Delta S U N_{t}$ \\
\hline \multirow[t]{2}{*}{$\overline{E C T_{\mathrm{t}}}$} & $(-0.0443)$ & 0.0743 & $E C T_{\mathrm{t}}$ & $(-0.0841)$ & $0.4216^{*}$ & $E C T_{\mathrm{t}}$ & $(-0.0063)$ & $0.0628 * *$ & $E C T_{\mathrm{t}}$ & 0.1118 & $0.8401 * * *$ \\
\hline & {$[-0.2277]$} & {$[-0.1497]$} & & {$[0.481]$} & {$[0.0127]$} & & {$[-0.802]$} & {$[0.0093]$} & & {$[-0.4786]$} & {$[1.1 \mathrm{e}-07]$} \\
\hline \multirow[t]{2}{*}{ Intercept } & $(-0.0009)$ & 0.0095 & Intercept & 0.0325 & $(-0.1426)^{*}$ & Intercept & $(-0.0003)$ & $(-0.0027)$ & Intercept & $(-0.0278)$ & $(-0.5893)^{* * *}$ \\
\hline & {$[0.8747]$} & {$[-0.2156]$} & & {$[0.4564]$} & {$[0.0208]$} & & {$[-0.9566]$} & -0.643 & & {$[-0.7962]$} & {$[5.3 \mathrm{e}-08]$} \\
\hline \multirow[t]{2}{*}{$\triangle R A P E_{\mathrm{t}-1}$} & 0.1334 & $(-0.3757)^{*}$ & $\triangle R A P E_{\mathrm{t}-1}$ & 0.0142 & $(-0.344)^{*}$ & $\triangle C P O I_{\mathrm{t}-1}$ & $0.3484 * * *$ & $(-0.0512)$ & $\triangle C P O I_{\mathrm{t}-1}$ & 0.3764 & 0.4867 \\
\hline & {$[-0.2569]$} & {$[0.0238]$} & & {$[-0.917]$} & {$[0.0743]$} & & {$[0.0001]$} & {$[-0.5401]$} & & {$[-0.3779]$} & {$[-0.2334]$} \\
\hline \multirow[t]{2}{*}{$\triangle C P O I_{t-1}$} & 0.1136 & $0.3884^{* * *}$ & $\triangle C P O I_{t-1}$ & 0.0045 & $0.6933^{* * *}$ & $\Delta S U N_{t-1}$ & $(-0.077)$ & $0.2353 * *$ & $\Delta S U N_{t-1}$ & $(-0.1732)$ & 0.8448 \\
\hline & {$[-0.1606]$} & {$[0.0008]$} & & {$[-0.9666]$} & {$[9.1 \mathrm{e}-06]$} & & {$[-0.3968]$} & {$[0.0073]$} & & {$[-0.1968]$} & {$[6.4 \mathrm{e}-10]$} \\
\hline \multirow[t]{2}{*}{$\triangle R A P E_{\mathrm{t}-2}$} & 0.1298 & 0.187 & $\triangle R A P E_{\mathrm{t}-2}$ & 0.1676 & 0.0846 & $\triangle C P O I_{t-2}$ & $(-0.0249)$ & 0.014 & $\triangle C P O I_{\mathrm{t}-2}$ & $(-0.2392)$ & $1.1395 * *$ \\
\hline & {$[0.2559]$} & {$[0.2434]$} & & {$[-0.2499]$} & {$[-0.6786]$} & & {$[0.7802]$} & {$[-0.8697]$} & & {$[-0.5851]$} & {$[0.0072]$} \\
\hline \multirow[t]{2}{*}{$\triangle C P O I_{\mathrm{t}-2}$} & $(-0.0602)$ & $(-0.0897)$ & $\triangle C P O I_{\mathrm{t}-2}$ & $0.4193 * *$ & 0.1551 & $\Delta S U N_{t-2}$ & 0.019 & $(-0.0194)$ & $\Delta S U N_{t-2}$ & 0.2984 & $4.3583 *$ \\
\hline & {$[0.4445]$} & {$[0.4171]$} & & {$[0.0035]$} & {$[-0.4354]$} & & {$[-0.8012]$} & {$[-0.788]$} & & {$[-0.8795]$} & {$[0.0217]$} \\
\hline \multicolumn{6}{|c|}{ AIC: -1836.98 ; SSR: 1.06564 ; Threshold: 0.2285364} & \multicolumn{6}{|c|}{ AIC: -1663.932 ; SSR: 1.487393 ; Threshold: 0.2896545} \\
\hline \multicolumn{6}{|c|}{ Cointegrating vector: $(1,-1.053278)$} & \multicolumn{6}{|c|}{ Cointegrating vector $:(1,-0.9307648)$} \\
\hline \multicolumn{6}{|c|}{ SupLM tast: 23.06327 : fixed, residual boostrap $(0.053 ; 0.028)$} & \multicolumn{6}{|c|}{ SupLM test: 21.63061 : fixed, residual boostrap $(0.088 ; 0.032)$} \\
\hline
\end{tabular}

Description: $* * *, * *, *$ significant at $1 \%, 5 \%$ and $10 \%$; The first line shows the estimated coefficient; The second line shows the standard error. 


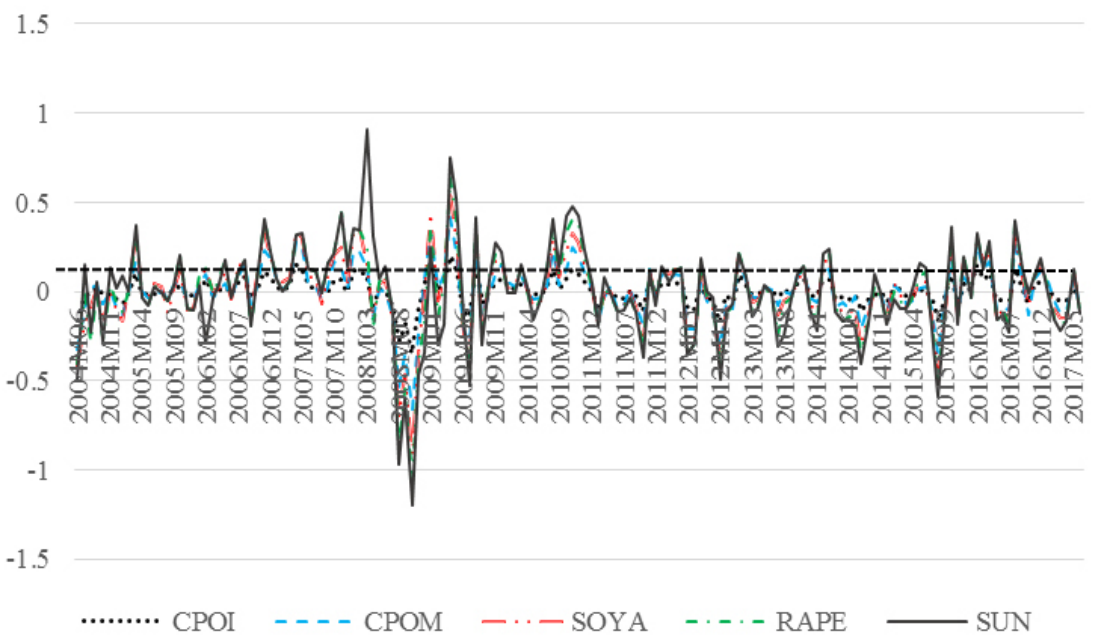

Figure 2. Movement of indonesian palm oil price adjustment in the world vegetable oil market

Market imperfection of world vegetable oil reflects the limited integration between the prices of vegetable oils. In addition, the transmission of price shocks in the world market to the domestic market does not occur immediately, but with some time lags. Overall, the model shows that in the long run, the price of Indonesian palm oil follows the rising prices for Malaysian palm oil, soybeans, and rapeseeds except sunflower oil. On contrary, the decline in the price of Indonesian palm oil will affect the price of soybean oil.

These results indicate that the price of Indonesian palm oil is still a price taker making the prices of Malaysian palm oil, soybean oil, and rapeseed oil the benchmarks in the export price formation. The export performance of Indonesian palm oil is inseparable from the development of world vegetable oil trade. As a price taker, Indonesia has not been able to contribute significantly to market pricing although it is the largest producer and exporter of world palm oi. Thus, the price of Indonesian palm oil is prone to a surge on other vegetable oil prices which have implications for the rapid loss of the positive margins received by the price of Indonesian palm oil.

However, there is still an opportunity for Indonesia to become a price leadership in the world vegetable oil market with the government support that must design adequate policy implementation to develop the downstream sector of palm oil products and increase the physical trade market infrastructure in supporting the development of futures exchanges as a place to establish and refer to palm oil prices so as to strengthen Indonesia's palm oil market position to lead the world vegetable oil market. The Indonesian commodity exchange, Jakarta Future Exchange and Indonesia Commodity Derivative Exchange (ICDX) in commodity trading have not been developed so that the government supports such as providing incentives in the form of tax deductions for each transaction in order to attract producers to enter the futures market to conduct palm oil trading in both hedging and investment are necessary.

\section{CONCLUSIONS AND RECOMMENDATIONS}

\section{Conclusions}

The treshold in long-term adjustments in the relationship between Indonesian palm oil and Malaysian palm oil, soybean oil, rapeseed oil and sunflower oil shows the adjustment of asymmetry transmission and competition among vegetable oils. In the long-term period, Indonesian palm oil price will respond more quickly to adjustments in the relatively large positive deviation (increase) from the threshold value to the market balance. This means that the price increase among other vegetable oil markets will be transmitted faster than the price decline.

The price of Indonesian palm oil follows the price movement of vegetable oils in the world market indicating that it is still a price taker and influenced by the price movement of Malaysian palm oil, soybean oil, rapeseed oil to serve as benchmarks in forming export prices. Other results show that in the long run, soybean oil prices also respond to the decline in Indonesian palm 
oil prices indicating that there is an opportunity for Indonesia to become a price maker and price leadership in the world vegetable oil market.

\section{Recommendations}

The government support in developing the future exchange as reference and a place to establish the price of world palm oil by developing palm oil products transacted with adequate physical trade infrastructure facilities is highly important. Therefore, they can support the downstream program and increase the export of Indonesian palm oil. Further studies are suggested to be carried out to identify the causes of asymmetric transmission marked by a threshold in price adjustment towards a long-term equilibrium. Research is needed to identify the most effective policies to overcome the inefficient transmission of price shocks among vegetable oils.

\section{ACKNOWLEDGMENT}

Gratitude is conveyed to the Ministry of Research and Higher Education of the Republic of Indonesia for providing scholarships and support for the research costs. Gratitude is also expressed for the opportunity to be a Workshop Participant in Research Output Quality Improvement in the Doctoral Dissertation Research scheme so that we can broaden our knowledge in writing a good scientific journal, and also to various parties who had helped this research ran well and smoothly.

\section{REFERENCES}

Abdulai A. 2000. Spatial price transmission and asymmetry in the ghanaian maize market. Journal of Development Economics 63(2): 327-349.https://doi.org/10.1016/S03043878(00)00115-2.

Abdullah R. 2013. An analysis on trends of vegetable oil prices and some factors affecting cpo price. Oil Palm Industry Economic Journal 13(2):114.

Aji BWP. 2010. Analisis integrasi harga minyak bumi, minyak kedelai, cpo, minyak goreng domestik dan tandan buah segar kelapa sawit [thesis]. Bogor: Sekolah Pascasarjana, Institut Pertanian Bogor.
Amiruddin MN, Rahman AK, Shariff F. 2005. Market potential and challenges for the malaysian palm oil industry in facing competition from other vegetable oils. Oil Palm Industry Economic Journal 5(1):17-27.

Ardeni PG. 1989. Does the law of one price really hold for commodity prices?. American Journal of Agricultural Economics 71(3): 661-669. https:// doi.org/10.2307/1242021.

Arianto ME et al. 2010. Analisis harga minyak kelapa sawit, tinjauan kointegrasi harga minyak nabati dan minyak bumi. Jurnal Manajemen dan Agribisnis 7 (1):1-19.

Balke NS, Fomby TB. 1997.Threshold cointegration. International Economic Review 38(1):627-645. https://doi.org/10.2307/2527284.

Buyung et al. 2017. The Analysis of factors affecting cpo export price of Indonesia. European Journal Of Accounting And Finance Research 5(7): 1729.

Chalil D. 2016. Sustainbility of sustainable palm oil a market integration analysis. Jurnal Manajemen dan Agribisnis 13(2): 157-167. https://doi. org/10.17358/JMA.13.2.157.

Chuangchid K et al. 2012. Factors affecting palm oil price based on extremes value approach. International Journal of Marketing Studies 4(6): 1918-1938. https://doi.org/10.5539/ijms. v4n6p54.

Costa NL, Santana AC. 2015. Exports and market power of the soybean processing industry in Brazil between 1980 and 2010. African Journal of Agricultural Research 10(26): 2590-2600. https://doi.org/10.5897/AJAR2014.9433.

Fernandez-Amador O, Baumgartner J, CrespoCuaresma J. 2010. Milking The Prices: The Role of Asymmetries in the Price Transmission Mechanism for Milk Products in Austria. Austria: Economics and Statistics. University of Innsbruck.

Fiamohe R et al. 2013. Price transmission analysis using threshold models: an application to local rice markets in Benin and Mali. Food SEC 5(1): 427-438. https://doi.org/10.1007/s12571-0130254-z.

Goetz L, Von Cramon-Taubadel S. 2008. Considering threshold effects in the long-run equilibrium in a vector error corrrection model: an application to thr german apple market. 12th Congress of the Europeaan Association of Agricultural Economists EAAE 2008. 
Hansen BE, Seo B. 2002. Testing for two-regime threshold cointegration in vector errorcorrection models. Journal of Econometrics 110 (2): 293-318. https://doi.org/10.1016/S03044076(02)00097-0.

In F, Inder B. 1997. Long-run relationships between world vegetable oil prices. Australian Journal of Agricultural and Resource Economics 41(4): 455-470. https://doi.org/10.1111/14678489.00024 .

Kouyate C, Von Cramon-Taubadel 2016. Proximity and price co-movement in west african rice markets. African Journal of Agricultural and Resource Economics 11(3): 167-182.

Meyer J, Von Cramon-Taubadel S. 2004. Asymmetric price transmission: a survey. Journal of Agricultural Economics 55(3): 581-611. https:// doi.org/10.1111/j.1477-9552.2004.tb00116.x.

Nakajima T. 2012. Asymmetric price transmission of palm oil: comparison between Malaysia and Indonesia. The Journal of Applied Economic Research 6(3): 337-360. https://doi. org/10.1177/097380101200600302.

Oil World. 2017. Oil World Data Base June 2017. Jerman: ISTA Mielke GmbH.

Owen A, Chowdhury K, Garrido J. 1997. Price interrelationships in the vegetable and tropical oils market. Applied Economics 29(1):119-124. https://doi.org/10.1080/000368497327470.

Peltzman S. 2000. Prices rise faster than they fall. Journal of Political Economy 108(3): 466-502. https://doi.org/10.1086/262126.
Peri M, Baldi L, 2010. Vegetable oil market and biofuel policy: an asymmetric cointegration approach. Energy Economics 32(3): 687-693. https://doi. org/10.1016/j.eneco.2009.09.004.

Priyati RY, Tyers R. 2016. Price relationship in vegetable oil and energy markets. Paper For Presentation At The Annual Australian Development Economics Workshop. Deakin University 9-10 June 2016.

Purwanto SK. 2002. Dampak kebijakan domestik dan faktor eksternal terhadap perdagangan dunia minyak nabati [thesis]. Bogor: Sekolah Program Pascasarjana, Institut Pertanian Bogor.

Rapsomanikis G, Hallam D. 2006. Threshold cointegration in the sugar-ethanol-oil price system in brazil: evidence from nonlinear vector error correction models. FAO Commodity and Trade Policy Research Working Paper No. 22.

Stigler M. 2010. Threshold cointegration: overview and implementation in R. https://cran. rproject.org/web/packages/tsDyn/vignettes/ ThCointOverview.pdf. [2 Juny 2017].

Suryana A. 1986. Trade prospects of indonesian palm oil in the International markets for fats and oils [dissertation]. Raleigh: North Carolina State University.

[USDA]. United State Departement of Agriculture. 2016. Oilseed and Product: World Market and Trade. Washington:USDA.

Vavra P, Goodwin BK. 2005. Analysis of Price Transmission Along Food Chain. Paris: OECD Publishing. 